\title{
A transformação da vida humana a partir da experiência de união com Deus
}

\author{
The transformation of human life from the experience of \\ union with God
}

Artur Viana do Nascimento Neto

\section{Resumo}

Uma vez criados à imagem e semelhança de Deus, naturalmente nossa vida está orientada para ele e para uma relação de intimidade com ele. Desta maneira, a vida espiritual se apresenta como um caminho de retorno às fontes (S1 87,7), que é Deus mesmo, diante de quem o homem pode se reconhecer e encontrar sua identidade. Em termos teresianos, esse caminho de retorno às fontes está bem representado na obra Castelo Interior ou Moradas, na qual Teresa de Jesus nos apresenta um itinerário não só de progresso espiritual como também humano. Reconhecendo a espiritualidade como o meio de transcender não prescindindo da humanidade, neste trabalho refletimos de que maneira a vivência da oração e seus efeitos transformam e repercutem nos vários âmbitos da vida humana. Trabalhamos com as sétimas moradas do Castelo Interior, conhecidas como as moradas da santidade, e abordamos o tema a partir de três perspectivas: espiritual, humana e apostólica. Tal reflexão nos convence de que a vida com Deus é uma viagem surpreendente e de acontecimentos imprevisíveis, marcada por transformações que tocam todos os âmbitos da vida humana.

Palavras-chaves: União com Deus. Transformação de vida. Santa Teresa de Jesus. Castelo Interior. Sétimas Moradas. 


\begin{abstract}
Once created in the image and likeness of God, naturally our life is oriented towards him and towards an intimate relationship with him. Hence, spiritual life presents itself as a way of returning to the sources (Psalm 87,7), which is God Himself, before whom mankind can recognize himself and find his identity. In Teresian terms, this path of return to the sources is well represented in the work The Interior Castle or The Mansions, in which Teresa of Jesus presents us with an itinerary of not only spiritual but also human progress. Recognizing spirituality as the means of transcending without neglecting humanity, in this paper we reflect on how the experience of prayer and its effects transform and impact on the various spheres of human life. We work with the seventh mansions of The Interior Castle, known as the abodes of holiness, and approach the theme from three perspectives: spiritual, human and apostolic. Such reflection convinces us that life with God is an amazing journey of unpredictable events, marked by transformations that touch all areas of human life.
\end{abstract}

Keywords: Union with God. Life Transformation. Saint Teresa of Jesus. The Interior Castle. The Seventh Mansions.

\title{
Introdução
}

O louvor e o reconhecimento serão sempre o primeiro movimento interior diante da misericórdia de Deus. E esse justo e natural movimento do coração testemunha nossa infinita dívida em face das incontáveis graças com que somos favorecidos. Santo Agostinho, já no início de sua clássica obra Confissões, inicia sua narrativa com esse mesmo sentimento:

Grande és tu, Senhor, e sumamente louvável; grande a tua força, e a tua sabedoria não tem limites. E quer louvar-te o homem, esta parcela e tua criação; o homem carregado com sua condição mortal, carregado com o testemunho do seu pecado e com o testemunho de que resistes aos soberbos; e, mesmo assim, quer louvar-te o homem, esta parcela da tua criação. Tu o incitas para que sinta prazer em louvar-te; fizeste-nos para ti, e inquieto está o nosso coração, enquanto não repousa em ti. ${ }^{1}$

${ }^{1}$ AGOSTINHO DE HIPONA, Confissões, I, 1. 
Com palavras imortais, Santo Agostinho não apenas se apresenta como alguém alcançado pela misericórdia de Deus e que, portanto, rende-lhe sua ação de graças, mas, para além disso, testemunha, em nome universal, a finalidade da vida humana: o louvor a Deus. Todavia, até mesmo esse movimento de reconhecimento é uma graça divina, pois sendo Deus o primeiro em tudo, não apenas nos ama antes de nós (1Jo 4,19), ${ }^{2}$ como é Ele mesmo o incitador do louvor: "Tu o incitas para que sinta prazer em louvar-te".

Segue, então, a chave de leitura que nos oferece o santo de Hipona para compreendermos a razão da vida humana: "fizeste-nos para ti, e inquieto está o nosso coração, enquanto não repousa em ti". Em termos mais desenvolvidos, o que se está dizendo é que fomos criados para um Outro, portanto para a relação, e também para um fim, o louvor de Deus; e diante desse projeto divino, vemos que fomos criados não acidentalmente ou que surgimos como resultado de experimento, mas fomos trazidos à vida por um desejo que nos quis e que não nos criou para vivermos fora dessa fonte criadora, mas, ao contrário, para vivermos em seu descanso, para participarmos de sua vida, para estarmos em sua "casa", e essa realidade não se apresenta como um caminho dentre muitos, mas o único que responde aos anseios humanos, de tal forma que, enquanto esta realidade de felicidade plena não acontece, "inquieto está o nosso coração". ${ }^{3}$

\section{Cristo, único caminho de união com Deus}

A grande novidade do Cristianismo é, em última instância, revelar-nos um Deus relacional, que não apenas tem interesse em nos resgatar das garras do pecado, mas, acima de tudo, um Deus que quer se unir a nós de modo pessoal. Em Cristo, já temos tudo revelado ${ }^{4}$ e já não mais precisamos de profetas, reveladores ou mensageiros extraordinários, e é o Espírito Santo, animador da Igreja, que se encarrega de nos fazer compreender a revelação de Cristo (Jo 14,26).

Essa união com Deus se apresenta no evangelho como um explícito desejo de Cristo. O próprio Jesus, em sua oração sacerdotal, intercede pela unidade dos cristãos entre si e pela união destes com as Pessoas Divinas:

\footnotetext{
${ }^{2}$ Como eco, pode-se ler em JOÃO DA CRUZ, Chama 3, 28: "Em primeiro lugar, é preciso saber que se a alma procura a Deus, muito mais a procura o seu Amado".

${ }^{3}$ No Saltério encontramos vários ecos dessa reflexão, podemos citar: Sl 42,2; 62,2; 63,2; 87,7.

${ }^{4}$ JOÃO DA CRUZ, 2 Subida 22, 3.
} 
Como tu, Pai, estás em mim e eu em ti, que eles estejam em nós, para que o mundo creia que tu me enviaste. Eu lhes dei a glória que me deste, para que sejam um, como nós somos um: eu neles e tu em mim, para que sejam perfeitos na unidade e para que o mundo reconheça que me enviaste e os amaste como amaste a mim (Jo 17,21b-23).

Essa união com Deus, da qual Cristo nos fez partícipes pelo mistério de sua vida humana, não é outra coisa senão o prêmio eterno que Deus tem reservado para nós desde sempre, cuja grandeza os olhos não podem vislumbrar, os ouvidos auscultar, nem o coração pressentir (1Cor 2,7-10). Com efeito, Deus nos criou para Si e foi o primeiro a mover-se para nos unir a $\mathrm{Si}$, pois é por meio dessa vida de união que Ele nos quer dar a imensa plenitude e incalculável felicidade de sua própria vida divina, e isso começando nesta vida. Esse é o fim para o qual Deus nos orienta e ao qual devemos tender com todas as forças.

De que modo, portanto, podemos chegar a essa união com Deus? Jesus mesmo nos responde: "Se alguém me ama, guardará minha palavra, e meu Pai o amará e a ele viremos e nele estabeleceremos morada" (Jo 14,23). Desta forma, vemos que o amor é o caminho da união, e quanto mais esse amor se fortalece, mais perfeita é nossa união com Deus. ${ }^{5} \mathrm{O}$ amor será sempre o termômetro de toda vida espiritual e o sinal de sua autenticidade, uma vez que é característica principal do seguidor de Jesus: "Nisto conhecerão todos que sois meus discípulos, se vos amardes uns aos outros" (Jo 13,35). Desta forma, não é possível ter uma vida mística (ou seja, uma vida de íntima amizade com Deus), nem uma verdadeira união com Deus se não formos proficientes nesse amor de uns para com os outros. Essa reflexão nos sugere também o Concílio Vaticano II:

E por isso, o amor de Deus e do próximo é o primeiro e maior de todos os mandamentos. Mas a Sagrada Escritura ensina-nos que o amor de Deus não se pode separar do amor do próximo, '...todos os outros mandamentos se resumem neste: amarás o próximo como a ti mesmo... A caridade é, pois, a lei na sua plenitude' (Rm 13,9-10; 1Jo 4,20). Isto revela-se como sendo da maior importância, hoje que os homens se tornam cada dia mais dependentes uns dos outros e o mundo se unifica cada vez mais. Mais ainda: quando o Senhor Jesus pede ao Pai 'que todos sejam um..., como nós somos um' (Jo 17,21-22), sugere - abrindo perspectivas inacessíveis à razão humana - que dá uma certa analogia

5 "Podemos, portanto, dizer que a alma pode ter tantos centros em Deus quantos graus de amor tiver, e uns mais profundos do que outros, porque o amor mais forte é o mais unitivo" (JOÃO DA CRUZ, Chama 1, 13). 
entre a união das pessoas divinas entre si e a união dos filhos de Deus na verdade e na caridade. Esta semelhança torna manifesto que o homem, única criatura sobre a terra a ser querida por Deus por si mesma, não se pode encontrar plenamente a não ser no sincero dom de si mesmo. ${ }^{6}$

Ao lermos os primeiros capítulos do Caminho de Perfeição, percebemos, desde já, a importância que dá Santa Teresa à relação amorosa de uns para com os outros, acompanhada do desapego de todo o criado e da humildade, apresentando-nos, assim, um tripé fundamental para a vida de oração. Apontando esses critérios, Teresa assume uma postura não menos que evangélica, que é mostrar como deve ser o caminho de todo aquele que quer ser amigo forte de Deus: encalçado na verdade (humildade), amando a Deus sobre todas as coisas (desapego das coisas criadas) e ao próximo como a si mesmo (amor de uns para com os outros): ${ }^{7}$

Antes, porém, de falar do interior, que é a oração, direi algumas coisas que é preciso ter as que pretendem seguir o caminho de oração. Elas são tão importantes que, se as tiverem, mesmo sem serem muito contemplativas, poderão estar muito adiantadas no serviço do Senhor. Mas, se não as tiverem, é impossível que sejam muito contemplativas e, quando pensarem que o são, estão muito enganadas. Peço ao Senhor que me conceda a sua ajuda e me mostre o que devo dizer, a fim de que seja para a sua glória. Amém. Não julgueis, minhas irmãs e amigas, que são muitas coisas que tenho para vos encarregar. Queira o Senhor que cumpramos as que os nossos Santos Padres ordenaram e guardaram, pois foi por este caminho que mereceram tal nome. Erro seria buscar outro ou não o aprender de ninguém. Alongar-me-ei tão somente a declarar três, que estão nas próprias Constituições, porque é de suma importância que entendamos o quanto nos convém guardá-las para alcançarmos, interior e exteriormente, a paz que o Senhor tanto nos recomendou. A primeira é o amor de uma para com as outras. A segunda é o desapego das coisas criadas. A terceira é a verdadeira humildade que, apesar de ser a última, é a principal e abrange a todas. ${ }^{8}$

Dentre os grandes ensinamentos que esses parágrafos podem nos aportar, vale a pena sublinhar o que nos diz a Santa em relação à muita importância que devem ter a essas três virtudes os que querem chegar à união com Deus, pois,

\footnotetext{
${ }^{6}$ GS 24.

${ }^{7}$ Eco dos textos evangélicos de Mt 22,34-40; Mc 12,28-31; Lc 10,25-28; Jo 13,34-35.

8 TERESA DE JESUS, Caminho de Perfeição 4, 3-4.
} 
como bem reforça a Santa Doutora, com a observância dessas virtudes, muito se adianta no serviço de Deus, e sem o cultivo delas, muito se engana quem pensa ter ido longe.

Como bem dissemos, o amor é o termômetro da vida espiritual, em outras palavras poderíamos dizer que o caminho das sete moradas do castelo interior não é marcado por outra coisa senão pela progressão no amor, que é o que nos indica qual nível de relação estamos com Deus e com os demais. De fato, quando vemos a vida de quem chegou à plena união com Deus - aqui consideramos o sujeito das sétimas moradas -, não observamos nela outra postura senão o exercício perfeito destas virtudes: a humildade que é andar na verdade de quem é Deus e de quem se é $;{ }^{9}$ o desapego de todo o criado que faz com que a mariposa encontre seu descanso em Deus, pois, uma vez livre de todas as coisas e até de si mesma, se torna um novo Cristo; ${ }^{10} \mathrm{e}$ o amor de uns para com os outros que, em sua perfeição, não se traduz apenas em tratar e querer bem aos demais, senão viver em função deles, num contínuo movimento de saída de si mesmo, reconhecendo nisso uma obra de Deus para a qual se deve empreender a vida. ${ }^{11}$

\section{A união com Deus em Santa Teresa de Jesus}

Em Contas de consciência, ou Relações, Teresa nos ilumina quanto ao tema da união com Deus, referindo-se já à união mística, portanto, a um estágio mais profundo da vida espiritual.

A respeito de me dar a entender o que é a união: "Não penses, filha, que a união é estar muito junto de Mim, porque os que me ofendem também o estão, embora não queiram. Também não são os regalos e os gostos da oração, ainda que sejam meus e de grau muito elevado; eles apenas são meios para muitas vezes ganhar as almas, até mesmo quando não estão em graça". (...) Voltando à união. Entendi que este espírito era limpo e estava acima de todas as coisas da terra; nele não há nada que se queira afastar da vontade de Deus que, desapegados de tudo e ocupados só em Deus, não há memória de amor a si mesmos nem a nenhuma coisa criada. Pensei

\footnotetext{
${ }^{9}$ TERESA DE JESUS, 6 Moradas 10, 7; 7 Moradas 4, 8. No aspecto de reconhecer-se quem se é, vale a pena destacar o tema da vigilância que tanto reforça Teresa nessas moradas, inclusive em cada um dos capítulos: TERESA DE JESUS, 7 Moradas 1, 8; 2, 9; 3, 14; 4, 3.

10 TERESA DE JESUS, 7 Moradas 2, 5.

11 TERESA DE JESUS, 7 Moradas 4, 6. 10. 14.
} 
comigo: se isso é união, então, de uma alma que permanece sempre nesta determinação, podemos dizer que está sempre em oração de união. ${ }^{12}$

Conforme às palavras do Senhor a Teresa, a união não se define por momentos específicos de oração, nem está condicionada a outros fatores externos como atos de culto, lugares sagrados, tampouco está presa a experiências interiores, como consolos, gozo na oração, embora, obviamente, todos esses elementos favoreçam e apareçam na vida espiritual.

Enquanto coube a Deus expor os não-critérios da união, toca, agora, a Teresa dizer por que sinais podemos identificar que uma pessoa está unida a Deus. Do que diz, podemos sintetizar em três pontos: 1. Limpeza de espírito (estado de graça); 2. Desapego das coisas da terra e até de si mesmo; 3. Conformidade com a vontade de Deus. Ou seja, a união com Deus assenta seus critérios mais no que se pode perceber no comum do dia a dia de uma pessoa, do que em momentos acidentais de oração ou em graças extraordinárias.

Partiremos desses três critérios apresentados por Teresa para vermos de que modo eles chegam a sua plenitude na união das sétimas moradas, ou, dito em outras palavras, como a pessoa humana, a partir da mais profunda união com Deus, dá sinais, em sua vida, de uma autêntica transformação humanoespiritual. Para nossa reflexão, distinguiremos três pontos, reescrevendo-os a partir dos critérios das Contas de consciência 29. Ao que diz respeito à limpeza de espírito (estado de graça), chamaremos transformação espiritual; ao lermos desapego das coisas da terra e de si mesmo, consideramos transformação humana; o que temos como conformidade com a vontade de Deus, abordaremos a partir do prisma do apostolado.

\subsection{Transformação espiritual}

O processo da união mística iniciado nas quintas moradas, robustecido nas sextas, chega à sua plenitude nas sétimas. Nestas moradas mais interiores, depois de haver passado por todas as purificações necessárias, o orante consuma sua união com Deus pela experiência do matrimônio espiritual. Tal experiência não só qualifica, ao máximo, a vida interior, como marca o ponto de chegada de todo o percurso da vida com Deus. Aqui são as moradas da santidade, que não é uma vocação particular dos místicos, mas um chamado para todos, isto é, todos os que buscam a Deus de coração sincero não só podem,

12 TERESA DE JESUS, Contas de consciência 29, 1-3. 
como deveriam adentrar essas moradas. Santa Teresa as apresenta em quatro capítulos: o primeiro, trinitário, trata da experiência da inabitação; o segundo, cristológico, testemunha a experiência do matrimônio espiritual; o terceiro, antropológico, se detém nos efeitos que causa na vida concreta essa experiência trinitária e cristológica; por fim, o quarto, apostólico ou eclesial, que é a razão pela qual se chega à santidade.

Os quatro formam uma unidade narrativa na qual a Santa faz uma síntese de toda sua experiência, e a propõe aos leitores como fundamento, meta e síntese da vida da graça, que não é outra coisa que o dom de Deus Pai em Cristo pelo Espírito. Por isso dizemos que as sétimas moradas são a grande doxologia teresiana como máxima expressão testemunhal da experiência trinitária. ${ }^{13}$

O progresso da vida espiritual é marcado pela intensidade com que se vive aspectos desta mesma vida, ou seja, há tanto união quanto purificação em cada uma das moradas, porém em intensidades diferentes. Quando citamos a experiência trinitária e cristológica como sinais da entrada nas sétimas moradas, não estamos dizendo que Teresa de Jesus teve tais experiências pela primeira vez somente agora neste grau de união, pois apenas voltando algumas páginas, nas sextas moradas, vemos as experiências cristológicas de Teresa por meio das alocuções ${ }^{14}$ e visões intelectuais ${ }^{15}$ e imaginárias ${ }^{16}$ de Cristo, por exemplo. A experiência da inabitação de Deus também pode ser vista em outros momentos da vida espiritual da Santa, como se lê em Vida: "outras vezes quando estava lendo, acontecia-me vir de repente um sentimento da presença de Deus. Eu não podia duvidar, de modo algum, que o Senhor estava dentro de mim e eu toda imersa Nele". ${ }^{17}$

No tocante à experiência trinitária, percebemos dois momentos distintos na vida de Teresa. Em um, a Santa entende, por graça, o que vem a ser o mistério da Santíssima Trindade:

Estando uma vez a rezar o salmo "Quicumque vult", fiquei muito admirada e consolada por me ter sido dado a entender de forma muito clara como Deus é um só em três Pessoas. Isso ajudou-me imenso para conhecer melhor a grandeza de Deus e as suas maravilhas. Por isso,

${ }^{13}$ LONDOÑO, R. C., Experiencia Trinitaria de Santa Teresa, p. 285. Tradução nossa.

14 TERESA DE JESUS, 6 Moradas 3.

15 TERESA DE JESUS, 6 Moradas 8.

16 TERESA DE JESUS, 6 Moradas 9.

17 TERESA DE JESUS, Vida $10,1$. 
quando penso ou ouço falar da Santíssima Trindade, parece-me que sei como isso é, o que me enche de alegria. ${ }^{18}$

Em outro momento, Teresa não só tem o entendimento do mistério trinitário, como se relaciona com a Trindade, gozando das Três Pessoas Divinas:

Esta presença das três Pessoas, de que falei ao princípio, tenho-a trazido até hoje, dia da Comemoração de São Paulo, frequentemente na minha alma. Como eu estava habitualmente a trazer só a Jesus Cristo, parece que me fazia algum estorvo ver três Pessoas, embora eu entenda que é um só Deus. Estando hoje a pensar nisso, o Senhor disse-me que era um erro pensar as coisas da alma, representando-as como as do corpo; que eu entendesse bem que elas são muito diferentes e que a alma tem capacidade para gozar muito. Tive a impressão de que Ele se me apresentou como quando se mete uma esponja a absorver a água; de igual modo parecia-me que a minha alma se enchia daquela divindade e, de alguma maneira, possuía e gozava em si dessas três Pessoas. Também entendi: "Não trates de me ter a Mim encerrado em ti, mas trabalha para te encerrares tu em Mim". Parecia-me que, a partir de dentro da minha alma - onde estavam e eu via estas três Pessoas - se comunicavam com todas as criaturas, não faltando nem deixando de estar comigo. ${ }^{19}$

Vemos, por esse testemunho, que, até esta data, Teresa iria considerar apenas Cristo em sua oração. Contudo, a partir dessa experiência relatada, a Santa desperta para uma relação trinitária, considerando também as demais Pessoas Divinas, e, todavia, estamos a dezessete meses da primeira experiência do matrimônio espiritual, graça mística própria e definitiva das sétimas moradas.

Diferentemente de outros êxtases da oração de união em que as potências eram suspensas e o entendimento não discorria, ${ }^{20}$ Teresa nos diz que, nesta experiência trinitária das sétimas moradas, "o nosso bom Deus já lhe quer tirar as escamas dos olhos para que veja e entenda alguma coisa da graça que Ele the concede, ainda que por uma estranha maneira", ${ }^{21}$ ou seja, Deus quer tornar o orante consciente dessa grande graça, fazendo-o não só compreender o mistério que ele crê por fé, mas também relacionando-se com as Pessoas Divinas, "falando-lhe e dando-lhe a entender aquelas palavras que o Evangelho diz de

\footnotetext{
${ }^{18}$ TERESA DE JESUS, Vida 39, 25. Ver também: TERESA DE JESUS, Vida 27, 9.

19 TERESA DE JESUS, Contas de consciência 18, Ávila, maio de 1571.

20 TERESA DE JESUS, Vida 18, 14, p. 123; 7 Moradas 1, 5.

21 TERESA DE JESUS, 7 Moradas 1, 6 .
} 
Jesus: Ele viria morar, com o Pai e o Espírito Santo na alma que o ama e guarda os seus mandamentos", ${ }^{22}$ e isso não só durante o momento em que se tem o êxtase, mas constantemente, de modo que "cada dia esta alma fica cada vez mais perplexa, porque, além de sentir que estas três Pessoas nunca se separam dela, vê claramente que, como foi dito, tem-nas dentro de si, no mais íntimo". ${ }^{23}$

Aqui vemos o detalhe particular da experiência trinitária das sétimas moradas: a constância da presença de Deus no orante, de forma que Teresa diz espantar-se por não deixar de sentir, por nenhum momento, essa divina companhia. Porém essa perenidade não diz respeito à visão enquanto fenômeno místico, mas à certeza de ser constantemente possuída, querida e habitada, "numa profundidade imensa, que não sabe explicar por não ter palavras". ${ }^{24}$ Como sublinha Londoño: "A Santa nos deixa ver que suas relações interpessoais com a Trindade cada dia lhe resultam mais fáceis e conaturais; que a Trindade das Pessoas divinas experimentadas de um modo progressivo, culmina em uma presença habitual". ${ }^{25}$

O fruto dessa graça é o aperfeiçoamento das virtudes e, novamente, a certeza contínua de estar sob o olhar de Deus e em suas mãos: "Encontrava-se melhorada em tudo. Parecia-lhe que, apesar de viver cheia de tribulações, com tantos problemas e afazeres, o essencial da sua alma nunca se movia daquele aposento". ${ }^{26}$

Apesar de ser grande essa experiência da Santíssima Trindade, "não é a meta das moradas, como algumas vezes se tem dito, mas sim o matrimônio espiritual. É certo que essa experiência [trinitária] acontece e, inclusive, antes do matrimônio, pois tem seu lugar no primeiro capítulo, prévio à graça matrimonial, como expressamente afirma Teresa", ${ }^{27}$ no entanto ela configura uma preparação para o matrimônio divino que se dará numa experiência cristológica, narrada por Teresa no capítulo 2, o qual começa dizendo e aclarando:

Falemos agora do divino e espiritual matrimônio, muito embora esta grande graça não se consuma de maneira perfeita enquanto vivermos na terra, porque, se nos afastássemos de Deus, perder-se-ia logo tão sumo bem. Quando Deus concede pela primeira vez esta graça, Sua Majestade quer manifestar-se à alma com uma visão imaginária da sua sacratíssima

22 TERESA DE JESUS, 7 Moradas 1, 6.

${ }^{23}$ TERESA DE JESUS, 7 Moradas $1,7$.

${ }^{24}$ TERESA DE JESUS, 7 Moradas 1, 7.

${ }^{25}$ LONDOÑO, R. C., Experiencia Trinitaria de Santa Teresa, p. 290. Tradução nossa.

26 TERESA DE JESUS, 7 Moradas 1, 10.

${ }^{27}$ CASTRO, S., Jesuscristo, plenitude de Moradas, p. 271. Tradução nossa. 
Humanidade, para que se dê bem conta e não ignore o dom tão supremo que recebe. ${ }^{28}$

Interessante perceber que também as experiências cristológicas foram se evolucionando ao longo da vida de Teresa. Logo no início da sua vida espiritual, em suas primeiras moradas, sua relação com Cristo era apenas a de trazê-lo à oração pela meditação dos eventos de sua vida:

Procurava o mais que podia trazer Jesus Cristo, nosso Bem e Senhor, presente dentro de mim. E o meu modo de oração era este: se meditava nalguma passagem [sobretudo da Paixão], representava-a dentro de mim; o resto gastava-o lendo bons livros. Deus não me deu talento para discorrer com a mente, nem tirar proveito da imaginação; aliás, trago-a tão entorpecida, que eu bem me esforçava por pensar e representar dentro de mim a Humanidade do Senhor, mas não conseguia. ${ }^{29}$

Desde então, a pessoa de Cristo esteve sempre presente na vida espiritual de Santa Teresa, sobretudo o mistério de sua Humanidade, que aparece, insistentemente, em seus escritos. Nos momentos cumes da sua vida, ali estava Jesus presente e atuante, por meio de experiências cristológicas. Assim o vemos na primeira experiência de arroubamento de Teresa, ${ }^{30}$ e, antes disso, no momento crucial de sua conversão, diante da imagem do Cristo chagado. ${ }^{31}$

Ao longo de todo seu processo espiritual, Cristo sempre esteve na centralidade, não só como prioridade, mas também como núcleo de atração, ${ }^{32} \mathrm{e}$ ao mesmo tempo, ao lado de Teresa, como companheiro no caminho. Não poucas vezes, vemos remissões, alusões, evocações da pessoa de Cristo na vida pessoal de Santa Teresa. As páginas de seus escritos estão recheadas de Cristo, e, na maioria das vezes, um Cristo explicitamente homem.

Para a Santa Doutora, a humanidade de Jesus não tem uma funcionalidade temporária, nem é um serviço que se presta ao orante que está galgando os primeiros degraus da vida espiritual, como pensavam as correntes de espiritualidade da sua época. ${ }^{33}$ Pelo contrário, a Humanidade de Cristo é indispensável em todas as etapas da vida interior, inclusive nas mais altas: "não

\footnotetext{
${ }^{28}$ TERESA DE JESUS, 7 Moradas 2, 1.

${ }^{29}$ TERESA DE JESUS, Vida $4,7$.

${ }^{30}$ TERESA DE JESUS, Vida 24, 5.

${ }^{31}$ TERESA DE JESUS, Vida 9, 1.

32 TERESA DE JESUS, Vida 40, 5; 1 Moradas 2, 1. 3. 8; 5M 1, 12; 7M 2, 3-4. 10.

${ }^{33}$ OSUNA, F., Tercer Abecedario Espiritual, p. 123; 127.
} 
queira outro caminho [fora da Humanidade de Cristo], ainda que esteja no cimo da contemplação. Por aqui vai seguro", ${ }^{34}$ tanto é que a experiência do matrimônio místico - graça que situa o orante no cume da vida espiritual - foi concedida a Teresa por meio de uma visão intelectual de Jesus Cristo em sua Humanidade, à qual ela aludirá:

Mas a esta, de quem falo [refere-se a si mesma], o Senhor, depois de ela ter comungado, apareceu-lhe ressuscitado em figura de grande resplendor, formosura e majestade e disse-lhe, entre outras palavras que são mais para sentir do que para dizer, que já era tempo de ela tomar como suas as coisas Dele e que Ele tomaria conta das dela. ${ }^{35}$

Assim como a experiência trinitária das sétimas moradas não foi a única, mas foi diferente das precedentes, aqui o mesmo sucede com a experiência cristológica. Como pudemos ver, estas foram muitas na vida de Teresa, Cristo sempre se the comunicou ao longo do percurso entre as moradas do castelo interior, às vezes de uma maneira, às vezes de outra. Ao falar sobre a graça do matrimônio espiritual, Teresa nos oferece uma chave de compreensão acerca das diferenças entre as mesmas experiências - aqui cristológica -, no que diz respeito à intensidade e aos efeitos que deixam.

Talvez pareça que esta manifestação não é novidade para a alma, pois o Senhor já se lhe tinha representado assim noutras ocasiões. No entanto, desta vez foi muito diferente, porque a deixou muito desorientada e assustada devido à impetuosidade desta visão e às palavras que Ele lhe dirigiu; além disso, à exceção da visão anterior [visão intelectual da Santíssima Trindade], nunca tinha tido outras como esta no íntimo da sua alma, onde se lhe representou. Sabei que entre as visões anteriores e a desta morada existe uma grande diferença. A diferença entre o desposório espiritual e o matrimônio espiritual é tão grande como a que existe entre os noivos e os casados, pois estes já não se podem separar. ${ }^{36}$

Esta singular experiências cristológica, que marca o matrimônio místico, é a graça maior e principal das sétimas moradas e se apresenta como "um dos aspectos mais inovadores do ápice da experiência teresiana" ${ }^{37}$. Sobre ela, dar-

\footnotetext{
34 TERESA DE JESUS, Vida 22, 7.

35 TERESA DE JESUS, 7 Moradas 2, 1.

36 TERESA DE JESUS, 7 Moradas 2, 2.

${ }^{37}$ LONDOÑO, R., Experiencia Trinitaria de Santa Teresa de Jesús, p. 530. Tradução nossa.
} 
nos-á Teresa todas as informações: quando, onde, como e qual efeito. A respeito de quando, Teresa nos conta com mais detalhes em Conta de consciência $35,{ }^{38}$ na qual narra ter recebido essa graça, pela primeira vez, durante a comunhão do dia 18 de novembro de 1572, pelas mãos de São João da Cruz, no mosteiro da Encarnação, do qual era priora à época; quanto ao onde: "esta secreta união passa no centro mais íntimo da alma, que deve ser onde está o próprio Deus e, segundo entendo, não precisa de porta para lá entrar", ${ }^{39}$ no que diz respeito ao como, dirá Teresa:

O Senhor aparece nesse centro da alma não por visão imaginária, mas intelectual - mais sutil ainda do que as referidas -, tal como apareceu aos apóstolos quando, sem entrar por qualquer porta, lhes disse: "Pax vobis". O que Deus comunica ali, num instante, à alma é um segredo tão grande e uma graça tão elevada que não sei a que hei de comparar o imenso gozo que a alma sente. Apenas sei que o Senhor quer lhe manifestar naquele momento a glória do céu de uma maneira muito mais sublime do que qualquer visão ou gosto espiritual. ${ }^{40}$

E quanto ao efeito, embora com as limitações naturais de traduzir em linguagem o que se vivenciou, dir-nos-á a Santa o que é essencial:

O que mais se pode dizer, tanto quanto se entenda, é que a alma, ou melhor, o espírito desta alma, torna-se uma só coisa com Deus. Sua Majestade, que também é espírito, quis mostrar o seu amor para conosco, dando a entender a algumas pessoas até que ponto Ele chega, a fim de louvarmos a sua grandeza. Na verdade, Ele quis unir-se de tal maneira à criatura que, à semelhança dos casados, não se quer separar dela. ${ }^{41}$

Essa união, malgrado sua profundidade e seus grandes frutos espirituais, na visão de Teresa, ainda não é a mais perfeita e a definitiva: "esta grande graça não se consuma de maneira perfeita enquanto vivermos na terra, porque, se nos afastássemos de Deus, perder-se-ia logo tão sumo bem". ${ }^{42}$ De certo modo, a Santa Doutora tem razão ao nos falar da incompletude dessa união, pois enquanto se vive nesta terra, nada pode ser pleno e perfeito ipsis litteris,

\footnotetext{
38 TERESA DE JESUS, Contas de consciência 35, Ávila, 18-11-1572.

39 TERESA DE JESUS, 7 Moradas 2, 3.

40 TERESA DE JESUS, 7 Moradas 2, 3.

41 TERESA DE JESUS, 7 Moradas 2, 3.

42 TERESA DE JESUS, 7 Moradas 2, 1.
} 
contudo tal graça guarda sua perfeição enquanto se é aquilo de mais alto e mais profundo a que se pode chegar estando neste mundo. A união desse matrimônio é tão inefável que, para explicá-la melhor, Teresa lançará mão de uma sucessão de imagens comparativas:

O que acontece aqui assemelha-se à água que cai do céu e se mistura com a do rio, ou da fonte, formando uma única água. Separá-las é impossível e não se sabe distinguir a água do rio da que caiu do céu; ou ao pequeno regato que entra no mar, não havendo maneira de os separar; ou a uma sala com duas janelas por onde entra muita luz: apesar de entrar separada, torna-se numa única luz. ${ }^{43}$

E depois de seus esforços para dar uma pálida imagem do que se experimenta aqui, Teresa resume, em termos cristológicos, os efeitos dessa graça, apoiando-se nas Escrituras: "Para mim viver é Cristo e morrer, um lucro' (Fp 1,21). Eu acho que a alma pode dizer aqui a mesma coisa, porque é agora que a borboletinha, de que falamos, morre, e morre num imenso gozo, porque Cristo já é sua vida" ${ }^{44}$ Com essas palavras, Santa Teresa nos mostra, claramente, a transformação espiritual que se dá no orante por meio dessa união das sétimas moradas: foi já cristificado, é um outro Cristo, e desta divina e profunda união brota uma paz verdadeira que nada pode perturbar. ${ }^{45}$ Parece que aqui mesmo se realizam aquelas palavras agostinianas: "Fizeste-nos para ti, e inquieto está o nosso coração, enquanto não repousa em ti". ${ }^{46}$

\subsection{Transformação humana}

O processo do homem novo acompanha, lado a lado, o progresso espiritual. Se, de fato, este é autêntico, aquele é inevitável. Já sabemos que, quando se leva uma sincera vida de amizade com Deus, a pessoa, em sua totalidade, se converte, assumindo não só uma nova forma de se relacionar com Ele, como também um novo comportamento diante das realidades da vida, e isso implica, necessariamente, uma transformação psicológica, ética, relacional.

A vida dos que começam a ser "servos do amor", isto é, daqueles que se determinam "a seguir, por este caminho da oração, quem tanto nos amou", ${ }^{47}$

43 TERESA DE JESUS, 7 Moradas 2, 4.

44 TERESA DE JESUS, 7 Moradas 2, 5.

45 TERESA DE JESUS, 7 Moradas 2, 9-11.

${ }^{46}$ AGOSTINHO DE HIPONA, Confissões I, 1.

${ }^{47}$ TERESA DE JESUS, Vida $11,1$. 
inicia seu processo de transformação integral desde as primeiras moradas, nas quais já se faz necessária uma abertura para o reconhecimento da verdade do que se é e enxergar a verdade de quem é Deus. Teresa insiste que o autoconhecimento é indispensável para o avanço na vida de oração, e, sem dúvida, é critério para a transformação que Deus quer operar no orante. ${ }^{48}$

Seguindo as moradas do Castelo Interior, podemos perceber, em todas elas, um comprometimento maior do homem que se aventura no caminho da oração: a primeira determinação em aderir a uma vida de comunhão com Deus; os esforços para continuar nela; as incoerências e dificuldades do percurso; as novas determinações; a conformidade e coerência de vida etc., tudo isso implica uma mudança de comportamento, de percepção do mundo, de relação com os outros e consigo mesmo. Da mesma forma, as purificações, provações, perseguições, características dos momentos noturnos desse caminho espiritual, contribuem, de modo fundamental, para esse amadurecimento humano.

Nas sétimas moradas, Santa Teresa apresenta o panorama humano do orante que chegou ao cume da vida espiritual, introduzindo a matéria com estas palavras: "Agora dizemos que essa borboletinha já morreu, com imensa alegria por ter encontrado repouso, e que é Cristo quem vive nela. Vejamos que vida tem agora, ou que diferença faz de quando vivia. Pelos efeitos veremos se aquilo que fica dito é verdadeiro". ${ }^{49}$ A Santa Doutora, ao falar sobre a vida nova do orante que agora encontrou em Deus descanso e plenitude, apresenta-o, primeiro, como um homem que precisou passar, necessariamente, pela morte. De fato, a vida nova em Cristo exige, naturalmente, uma morte do homem velho, um abandono de antigos costumes, uma nova valorização de certos princípios, e isso em função de um referencial: Cristo, pois agora é a vida Dele, agora é para Ele a vida.

Ao longo do capítulo, Teresa articula seu texto em duas partes: "por um lado, a nova maneira de ser, de viver e de atuar do cristão que chegou a esse estado (aspectos psicológicos, éticos), e por outro, o 'particular cuidado que Deus tem de comunicar-se com ele' (aspecto teologal). A santidade cristã é a plena comunhão do homem com Deus". ${ }^{50}$

Partindo disso, a Santa nos elenca os frutos dessa nova vida, da vida em matrimônio com Cristo, que são, em primeiro lugar, um esquecimento de si, que é um comportamento muito próprio de quem está aberto verdadeiramente ao amor. A libertação do egocentrismo e das intenções egoístas - não só aquelas

48 TERESA DE JESUS, 1 Moradas 2, 8-9.

49 TERESA DE JESUS, 7 Moradas 3, 1.

${ }^{50}$ ÁlVAREZ, T., Comentarios, p. 308. Tradução nossa. 
que podem causar grandes danos, senão também as aparentemente justas e lícitas $^{51}$ - é o fruto maior de quem experimentou, em alta voltagem, uma misericórdia desconcertante e um amor inexplicável. Precisamos recordar que esse esquecimento de si é uma das formas de amor provado que Cristo demonstra em toda sua vida (Fp 2,6-11), e como Ele deve ser sua esposa, que já não vive mais para si, senão em função Daquele que ama e a quem se entregou: "encontra-se toda ocupada em procurar a honra e glória de Deus (...) por essa causa, de boa vontade daria a vida (...) por nada desse mundo deixaria de fazer tudo o que pode e entende que é serviço de Nosso Senhor". ${ }^{2}$ Obviamente isso implica uma vida proativa, em constante desejo de fazer algo por Deus, de servir-lhe de todas as formas possíveis.

Em segundo lugar, apresenta um grande desejo de padecer por Deus, mas, ao mesmo tempo, acrescenta: "mas não de maneira a consumir-se como antes. Na verdade, o desejo que fica nestas almas para que se faça nelas a vontade de Deus, é tão intenso que acham bem tudo a que Sua Majestade faz. Se Ele quer que ela padeça, que seja em boa hora; e, se não, já não se consome como antes". ${ }^{53}$ Isto quer dizer que, por mais que sejam um bom sinal os grandes desejos de oferecer a Deus sofrimentos, padecimentos, ainda são imaturos e não purificados quando lhes acompanha a inquietação proveniente da sua não satisfação. Aqui Teresa nos oferece uma grande chave de leitura: por mais que sejam heroicos os ímpetos de se oferecer a Deus pela humanidade, ainda assim o que parece ser virtude e boas intenções pode estar sendo vivido ainda de modo imperfeito, pois a perfeição consiste não em fazer, mas em ser, dessa forma, se se é aquilo que Deus quer que se seja, qualquer realização de Sua vontade vale muito mais do que a realização dos próprios desejos, por mais que sejam mui virtuosos. Neste ponto, Teresa coloca a tônica na vontade de Deus, e isso deixará bem expresso no seu poema Vossa sou, para vós nasci: "Se me quereis descansando,/ quero, por amor, folgar;/ se me mandais trabalhar,/ quero morrer trabalhando./ Dizei onde, como e quando/ dizei, doce amor, por fim./ Que mandais fazer de mim?" 54 .

Como extensão desse fruto, há outro semelhante apontado pela Santa, que, segundo ela, causou-lhe grande espanto: a mudança em relação ao desejo

\footnotetext{
${ }^{51}$ Desapego de coisas, mesmo que devotas, TERESA DE JESUS, Vida 26, 5. Desapego de pessoas, ainda que, aparentemente, não ofendesse a Deus tratando com elas: TERESA DE JESUS, Vida 24, 5.

52 TERESA DE JESUS, 7 Moradas 3, 2-3.

${ }^{53}$ TERESA DE JESUS, 7 Moradas 3, 4.

${ }^{54}$ TERESA DE JESUS, Poesia Vossa sou, para vós nasci, p. 964.
} 
de morrer. O tema "morte", na experiência de Santa Teresa, passou por suas evoluções, desde o grande temor que tinha por ela, ${ }^{55}$ até os grandes ímpetos de morrer, ${ }^{56}$ característicos de um estágio espiritual ainda imaturo. Muitas vezes enaltecemos, encantados, esse grande desejo do místico de logo se ver livre desta vida para gozar de Deus, e não pensamos que talvez esse ímpeto, aparentemente virtuoso, possa ser um reflexo de um desejo ainda não purificado, uma vontade cheia de boas intenções, mas ainda enraizada no egoísmo. No entanto, sabemos bem que esses sentimentos, na vida espiritual, fazem parte do processo de maduração e configuram a reordenação e harmonização do homem sensitivo com o homem espiritual. A libertação desses ímpetos, que às vezes consideramos bonitos e nobres, é caracterizada por Teresa como libertação de "tormentos e aflições que estas almas passaram com os desejos de morrer para gozar de Nosso Senhor", ${ }^{57}$ justamente para melhor cumprir a vontade de Deus, que, dito em palavras teresianas, significa "ajudar o Crucificado no que puderem, sobretudo quando o veem tão ofendido e quão poucos são os que, despendidos de tudo, zelam verdadeiramente pela sua honra" ${ }^{58}$ Aqui a experiência de Deus repercute na vida do orante de outra maneira, não mais - como antes - com desejos deste de logo se ver gozando de Deus, mas, ao contrário, desejando vida e impulsionando-o a sair de si e trabalhar para que esse Deus da experiência seja conhecido e amado por muitos:

Pois, agora, é tão grande o desejo que têm de o servir, de o louvar e de poder ajudar alguma alma, que, além de não querer morrer, desejam viver muitos e muitos anos, padecendo os maiores tormentos, para ver se conseguem que o Senhor seja louvado por meio deles, mesmo que fosse em muito pouca coisa. ${ }^{59}$

Teresa fala isso partindo da própria experiência, como nos dirá em Contas de consciência: "Os enormes ímpetos e desejos de morrer se me acabaram, sobretudo a partir do dia de santa Madalena, em que me determinei a viver de boa vontade para servir muito a Deus". ${ }^{60}$

\footnotetext{
55 TERESA DE JESUS, Vida 38, 5.

56 TERESA DE JESUS, Vida 16, 1; 29, 8; 33, 8; Caminho de Perfeição 31, 8; 5 Moradas 2, 7; 6 Moradas 6, 1; 7, 3; 11, 2. 9; Poesias Vivo sem viver em mim, p. 963; Que triste é, meu Deus, sem ti o viver!, p. 967.

57 TERESA DE JESUS, 7 Moradas 3, 6.

58 TERESA DE JESUS, 7 Moradas 3, 4.

59 TERESA DE JESUS, 7 Moradas 3, 6.

${ }^{60}$ TERESA DE JESUS, Contas de consciência 21. Pode-se ler também a Conta de consciência 42.
} 
Na sequência dos frutos, Teresa também fala do grande gozo interior que sente quem passa por perseguições, e acrescenta:

Têm muito mais paz do que anteriormente e não sentem qualquer inimizade para com aqueles que fazem ou desejam fazer-lhes mal; pelo contrário, ganham-lhes um amor especial. Se os veem nalguma aflição, logo se compadecem deles e estariam dispostas ao que fosse para os livrar dela; de todo o coração encomendam-nos a Deus; e gostariam de perder algumas das graças que Sua Majestade lhes faz, para que, fazendo-as a eles, não ofendessem mais a Nosso Senhor. ${ }^{61}$

Aparentemente é apenas aqui que se pode viver com perfeição aquele mandamento de Jesus que diz: "amai os vossos inimigos e orai pelos que vos perseguem" (Mt 5,44). Realmente, uma das grandes novidades do Cristianismo, no que diz respeito à relação com o outro, é o amor aos inimigos. Por mais que exista uma defesa do perdão, um estímulo à escusa por parte de outras religiões, o Cristianismo, de modo muito característico, é a religião que não apenas encoraja o amor e a oração pelos inimigos, como torna essa postura num mandamento. Sabemos por experiência que, por nossos esforços, muito conseguimos fazer quando perdoamos nossos inimigos, e isso não sem renúncia de si, porém amar e orar pelos inimigos requerem talvez uma perfeição de vida que só quem a tem é aquele que já vive em Cristo de modo pleno, de forma que é Cristo mesmo quem ama, perdoa e ora.

Aqui o cristão santificado já não faz caso de gostos e consolações, pois, nessa união perfeita, já tem tudo que poderia querer, e bem mais do que poderia merecer. Da mesma forma, está desapegado de todas as coisas, desejando apenas o único e necessário: "estar sempre sozinhas ou ocupadas em coisa que aproveite a alguma alma". ${ }^{62}$ Nestas moradas, já não há mais aridez nem alvoroços interiores,${ }^{63}$ tampouco arrebatamentos e êxtases,${ }^{64}$ pois o orante já encontrou descanso em Deus, já provou tanto Dele que não mais se impressiona com essa doce e constante companhia, suas capacidades foram ampliadas, agora goza apenas de uma paz suave com seu Esposo: "o mesmo acontece nesse templo de Deus, nesta sua morada, onde só Ele e a alma se gozam mutuamente num profundo silêncio". ${ }^{65}$

61 TERESA DE JESUS, 7 Moradas 3, 5.

${ }^{62}$ TERESA DE JESUS, 7 Moradas 3, 8.

${ }^{63}$ TERESA DE JESUS, 7 Moradas 3, 10.

${ }^{64}$ TERESA DE JESUS, 7 Moradas 3, 12.

65 TERESA DE JESUS, 7 Moradas 3, 11. 
Esses frutos, por sua vez, seguem se desenvolvendo na vida do orante, à medida que ele persevera na vivência desse mistério da união com Deus. Um ponto de muita importância, enquanto fruto dessa experiência transformadora, é que "a pessoa não permanece nessa fruição e gozo da presença e ações de Deus nela, tampouco fica ensimesmado e encerrado em si, pois as sétimas moradas já é um tempo de entrega, abertura e serviço radical", ${ }^{66}$ como veremos a seguir.

\subsection{Santidade para a Igreja}

No último capítulo das sétimas moradas, Santa Teresa conclui seu tratado resumindo, em uma frase, o sentido último da vida espiritual: "Será bom dizervos, irmãs, a finalidade pela qual o Senhor concede tantas graças neste mundo (...): dar-nos uma vida semelhante à do seu muito amado Filho". ${ }^{67}$ Aqui fica claro qual o fim da união com Deus, que não é outro senão a plena configuração com Cristo, e é esta conformidade de vida que dá razão a todo o percurso do Castelo Interior, é ela que justifica, ademais, toda uma existência marcada pela busca da vontade de Deus.

Porém que imagem de Cristo Teresa evoca nestas moradas? O Cristo ressuscitado, que já não mais padece? O Cristo ascendido aos céus, que já goza da sua glória à direita do Pai? Não, mas a do Cristo Crucificado, que carrega sua cruz e que se imola por todos. São esses, portanto, os dois expoentes fundamentais da vida de quem atingiu as sétimas moradas: 1 . A participação da cruz de Cristo por meio das contrariedades, desafios e provações do dia a dia, porque, embora aqui se tenha chegado à santidade, a realidade da vida quotidiana não passa a ser feita de situações paradisíacas, extáticas e isentas de perigos e tentações, pelo contrário, Teresa lembra que aqui não se está poupado de nenhuma queda, mas que se deve sempre estar vigilante, pedir "que Sua Majestade nos ampare sempre, que nos assista para não o ofendermos é a melhor segurança que podemos ter", ${ }^{68}$ e se manter sempre alicerçado na humildade, para que "colocando pedras muito firmes, não se lhes caia o castelo"; ${ }^{69}$ 2. O serviço incondicional aos irmãos, ao exemplo de Cristo que se ofereceu por todos e nunca mediu esforços para se dar cada vez mais. Se há, portanto, uma perfeita configuração com Cristo Crucificado, há, necessariamente, uma perfeita participação dessas duas dimensões de sua vida,

\footnotetext{
${ }^{66}$ ANDUEZA, V. T., Cómo iniciar en la experiencia de Dios, p. 138. Tradução nossa.

${ }^{67}$ TERESA DE JESUS, 7 Moradas 4, 4.

68 TERESA DE JESUS, 7 Moradas 4, 3.

${ }^{69}$ TERESA DE JESUS, 7 Moradas 4, 8.
} 
que Teresa resume magistralmente dizendo: "Sabeis o que é ser verdadeiramente espirituais? É fazer-se escravos de Deus, marcados com o seu ferro, que é a cruz; desta maneira, tendo-lhe já entregue a sua liberdade, pode vendê-los como escravos de todo o mundo, como Ele foi". ${ }^{70}$

Essa dimensão do serviço, contudo, supera a ideia errônea de que o orante das sétimas moradas, de tão unido que está com Deus, não sabe levar outro apostolado senão o de orar pelos outros na solidão do seu recolhimento, nos seus incontáveis momentos de contemplação e de orações devotas. Exatamente o contrário, "a esposa, vivendo definitivamente na Trindade, não tem já outro contento que gozar de seu Amado e busca contentá-lo em tudo quanto realiza: é uma vida plena e capacitada para gerar obras"71. Dirá Teresa, em outro contexto, mas mui acertadamente: "Deus me livre de gente tão espiritual que, dê no que der, quer em tudo contemplação perfeita". ${ }^{72}$

Indo, talvez, na contramão do que, geralmente, se pode pensar acerca do perfil de santidade - sobretudo se se trata de místico -, Teresa não hesita em dizer que o serviço, o apostolado, as obras, a vida ativa não são apenas um chamamento para uma parcela dos cristãos, os quais - pode-se pensar - não foram favorecidos pela graça de poderem sempre estar contemplando, mas, assim como a oração é indispensável para a santidade, não é possível ser santo estando encerrado em si mesmo, com a justificativa de ser um espiritual contemplativo. A Santa será categórica ao apresentar o apostolado como fruto de uma profunda vida de oração: "A oração é para isso, minhas filhas, e o matrimônio espiritual é para que nasçam sempre obras e mais obras". ${ }^{73}$

Não é apenas em uma ocasião que Teresa insistirá nesse ponto, senão em várias outras no mesmo capítulo: "Para isso, volto a repeti-lo, é preciso que não ponhais o vosso alicerce só em rezar e contemplar; porque, se não procurais adquirir e praticar as virtudes, ficareis sempre anãs"74. As obras são vitaminas para o organismo espiritual, também elas são indispensáveis para o crescimento do orante.

Teresa nos faz perceber também que, nestas moradas finais, o cristão deve saber conjugar oração e ação, apresentar uma perfeita unidade entre ser e fazer, pois um nunca está desconectado do outro, mas são ambos companheiros

\footnotetext{
70 TERESA DE JESUS, 7 Moradas 4, 8.

${ }^{71}$ ANDUEZA, V. T., Cómo iniciar en la experiencia de Dios, p. 140. Tradução nossa.

72 TERESA DE JESUS, Certame 7.

73 TERESA DE JESUS, 7 Moradas 4, 6.

74 TERESA DE JESUS, 7 Moradas 4, 9.
} 
que se reclamam mutuamente. Para isso, a Santa se vale da imagem de Marta e Maria, a partir do que, geralmente, se acentua de cada uma delas.

É isto, minhas irmãs, o que eu quero que procuremos alcançar. Desejemos e façamos oração, não para gozar, mas para termos mais forças para servir. (...). Acreditai-me que Marta e Maria devem andar sempre juntas para hospedar o Senhor, recebendo-o como deve ser, isto é, fazer-lhe companhia e dar-lhe de comer. Sentada sempre a seus pés, como é que Maria lhe poderia dar de comer se não fosse ajudada pela sua irmã? O alimento do Senhor é que, por todos os meios que pudermos, ganhemos almas para que se salvem e o louvem por toda a eternidade. ${ }^{75}$

A imagem das duas irmãs de Bethânia é um resumo muito acertado do perfil do cristão transformado por Deus. Tudo aqui está em harmonia e ordenado, a contemplação fecunda em obras e estas refletem uma verdadeira experiência de Deus, pois quando se contrai o matrimônio espiritual, os interesses do Esposo são os mesmos da esposa, as prioridades de Cristo são já as do cristão transformado. Nestas moradas, oração e ação, trabalho e contemplação nunca foram tão complementares como agora e viver a partir delas nunca pareceu tão inevitável. Em Meditação sobre os Cantares, ou Conceitos do Amor de Deus, Santa Teresa também evoca essa imagem de Marta e Maria e, com o que escreve, nos oferece uma leitura importantíssima acerca da união desses dois aspectos:

Essas flores não têm o mesmo perfume das que cheiramos por cá. A meu ver, ela [a alma] pede aqui para fazer grandes obras ao serviço de Nosso Senhor e do próximo; daí o regozijar-se por perder aquele deleite e contentamento. Apesar de ser uma vida mais ativa do que contemplativa, e lhe parecer que ficará a perder se o seu pedido for atendido, quando a alma chega a esse estado, Marta e Maria trabalham quase sempre juntas. Com efeito, na ação e naquilo que parece exterior é o interior que atua; e, quando as ações brotam desta raiz, transforma-se em admiráveis e perfumadíssimas flores. E porque brotam desta árvore do amor de Deus, cujo único interesse é servi-lo, o perfume destas flores espalha-se para proveito de muitos. Este é um perfume que dura, demora em desaparecer, e faz obras extraordinárias. ${ }^{76}$

75 TERESA DE JESUS, 7 Moradas 4, 12.

76 TERESA DE JESUS, Conceitos do amor de Deus 7, 3. 
O amor impulsiona o cristão a ir sempre mais adiante, além de si, manifestando sua experiência de Deus nas mais diversas maneiras. A oração é o motor que faz nascer as obras e, ao mesmo tempo, que as qualifica. As obras, por sua vez, são o testemunho vivo de uma experiência autêntica, de um encontro verdadeiro com um Deus vivo e pessoal.

\section{Conclusão}

Muitas vezes podemos pensar que as sétimas moradas, ou a santidade, são a etapa da vida espiritual marcada pela profusão dos fenômenos místicos, penitências estritas, horas sem fim de oração, como se o orante estivesse num contínuo êxtase e aparentasse não ter mais nenhuma relação com essa terra. No entanto, a partir do que nos pontua Teresa de Jesus, a santidade não se assenta em nada disso, mas se caracteriza por ser uma vida de profunda união com a vontade de Deus, como também de um profundo ardor apostólico que inquieta o orante e o leva a servir incansavelmente pelo bem da humanidade. Numa espécie de síntese, resume Tomás Álvarez:

Em que consiste a santidade cristã? Em quatro capítulos, quatro respostas: a santidade cristã é, antes de tudo, um fato trinitário acontecido no homem; é um fato cristológico de plena incorporação a Cristo; um fato antropológico de plenitude e maturidade humanas; e, finalmente, é um fato eclesial, carisma outorgado à pessoa para edificar o corpo místico de Jesus aqui na terra, a serviço dos homens. ${ }^{77}$

Deus quer se unir a nós de uma forma inseparável, esse é seu desejo e deve ser essa nossa única ambição. A perfeição de vida, enquanto consumação dessa união tão desejada, é fruto de um processo lento que avança conforme as disposições do orante, pois quanto mais este se abre à graça de Deus, mais Deus pode operar em sua vida e transformá-la.

A santidade é a vocação universal para a qual todos são chamados, não apenas uma parcela do povo de Deus; tampouco atingir a santidade requer uma predestinação, senão uma adesão sincera e determinada ao projeto de Deus que é santificar a todos e atrai-los para $\mathrm{Si}$.

Chegado ao cume da vida espiritual, Teresa nos apresenta as características fundamentais daquele que chegou à santidade pelo caminho da oração: se o cristão chega a ser santo é porque a Trindade habita e reina no seu

77 ÁlVAREZ, T., Comentarios, p. 314-315. Tradução nossa. 
mais profundo centro; porque há uma configuração total a Cristo de modo que Ele é quem vive; o homem novo desenvolve as virtudes e a vida teologal, mudando sua forma de enxergar o mundo e de viver nele; e, por fim, é um homem lançado para fora, "servo do amor", "escravo de Deus", ao mesmo tempo Marta e Maria. Nenhuma novidade para além da proposta do evangelho e da própria vivência do batismo.

Que esta reflexão acerca da santidade nos permita ver com outros olhos essa etapa de perfeição cristã, que muitas vezes caricaturamos e, na ânsia de encontrarmos santos extraordinários, não identificamos os santos ordinários com os quais, não poucas vezes, convivemos no nosso dia a dia.

\section{Referências bibliográficas}

AGOSTINHO DE HIPONA. Confissões. São Paulo: Paulus, 1984.

ÁlVAREZ, T. Comentarios al 'Castillo Interior' de Santa Teresa de Jesús. Burgos: Monte Carmelo, 2011.

ANDUEZA, V. T. Cómo iniciar en la experiencia de Dios: mistagogía teresiana en el Castillo Interior. Burgos: Monte Carmelo, 2004.

BÍBLIA de Jerusalém. Nova ed. rev. e ampl. 7.impr. São Paulo: Paulus, 2011.

CASTRO, S. Jesucristo, plenitud de Moradas, o Moradas, la revelación de una cristofanía. In: Congreso Internacional Teresiano, 4, 2013, Ávila. Las Moradas del Castillo Interior de Santa Teresa de Jesús. Burgos: Monte Carmelo, 2014. p. 251-273.

CONCÍLIO VATICANO II. Constituição Pastoral Gaudium et Spes sobre a Igreja no mundo atual. Disponível em: $<$ http://www.vatican.va/archive/hist_councils/ii_vatican_council/documents/vat -ii_const_19651207_gaudium-et-spes_po.html>. Acesso em: 08 mar. 2020.

JOÃO DA CRUZ. Chama de amor viva. In: JOÃO DA CRUZ. Obras completas. Marco de Canaveses: Edições Carmelo, 2005. p. 737-822.

JOÃO DA CRUZ. Subida do Monte Carmelo. In: JOÃO DA CRUZ. Obras completas. Marco de Canaveses: Edições Carmelo, 2005. p. 141-398.

LONDOÑO, R. C. Experiencia Trinitaria de Santa Teresa de Jesús. Burgos: Monte Carmelo, 2004. 
LONDOÑO, R. C. Experiencia Trinitaria de Santa Teresa. In: Congreso Internacional Teresiano, 4, 2013, Ávila. Las Moradas del Castillo Interior de Santa Teresa de Jesús. Burgos: Monte Carmelo, 2014. p. 275-291.

OSUNA, F. Tercer Abecedario Espiritual. Madrid: Biblioteca de Autores Cristianos, 1972.

TERESA DE JESUS. Caminho de Perfeição. In: TERESA DE JESUS. Obras completas. Marco de Canaveses: Edições Carmelo, 2015. p. 305-432.

TERESA DE JESUS. Castelo Interior. In: TERESA DE JESUS. Obras completas. Marco de Canaveses: Edições Carmelo, 2015. p. 443-590.

TERESA DE JESUS. Certame. In: TERESA DE JESUS. Obras completas. Marco de Canaveses: Edições Carmelo, 2015. p. 986-988.

TERESA DE JESUS. Conceitos do amor de Deus. In: TERESA DE JESUS. Obras completas. Marco de Canaveses: Edições Carmelo, 2015. p. 855-894.

TERESA DE JESUS. Contas de consciência. In: TERESA DE JESUS. Obras completas. Marco de Canaveses: Edições Carmelo, 2015. p. 789-850.

TERESA DE JESUS. Livro da Vida. In: TERESA DE JESUS. Obras completas. Marco de Canaveses: Edições Carmelo, 2015. p. 31-299.

TERESA DE JESUS. Poesias. In: TERESA DE JESUS. Obras completas. Marco de Canaveses: Edições Carmelo, 2015. p. 963-982.

Artur Viana do Nascimento Neto Mestrando em Mística e Ciências Humanas pela Universidad Católica de Ávila Centro Internacional Teresiano Sanjuanista - CITeS Ávila - Espanha E-mail: arturviananeto@yahoo.com.br

Recebido em: 30/03/2020

Aprovado em: 18/08/2020 